\title{
SUSTAINABLE DEVELOPMENT AND GREENING THE ECONOMY IN TRANSITION COUNTRIES IN SE EUROPE: A CASE STUDY OF BOSNIA AND HERZEGOVINA
}

\author{
Melika Arifhodzic ${ }^{1}$
}

\begin{abstract}
In order to become members of EU, countries in transition in SE Europe have been under pressure of introducing measures and laws relating to environmental protection. The urge is getting higher as the natural resources and biodiversities, which are amongst the highest in level in the continent, are under constant threat due to improper use or unplanned exploitation. Considering the still existing traces left from the legacy of centrally planned economy and political systems, the paper will question how some models of sustainable development in Europe are applicable in these countries. Through various shifts of social, economic and political indicators the paper will analyze their influences in relation to implementation of sustainable development policy as well as activities in connection to green economy introduction. An intensive approach will be employed in case of Bosnia and Herzegovina and the results of various studies and cases from the practice will prove that all these mentioned factors play a key role in planning of sustainable development. The conclusion is that an approach that takes into consideration all named factors, integrating researchbased and practice-based knowledge should be proposed for these countries.
\end{abstract}

Key words: Environmental protection, Sustainable Development, Transition, Green Economy, SE Europe, Bosnia and Herzegovina.

\section{INTRODUCTION}

The pressure of the EU to the countries in transition to make environmental law and policies harmonization to European laws is getting stronger. This balance is posed as obligatory for these countries if they want to become EU members. This is a very demanding task for them: besides a burdening transition process from centrally planned economy to free market, the adoption of the entire EU Environmental Acquis also requires extensive changes to the existing institutional and legal framework. In recent times, concept of green economy has become an inseparable part in many EU strategic documents and plans. Green economy has become an answer to environmental concerns as it uses efficiently natural and ecosystem resources and services; it is socially inclusive, energy efficient and significantly reduces risk to the environment. In this paper we will try to generally evaluate the appropriateness of the green economy introduction in the countries in transition in SE Europe, particularly in Bosnia and Herzegovina. We will briefly overview to which extent differences in political and economic background, ethnic issues and influencing legacy from the previous system affect the prospects of greening the economy of the countries.

In Bosnia and Herzegovina, after the Dayton peace Agreement some progress has been made in terms of legal framework in environmental policies but a broader and systematic "green" transition is lacking (FBiH Report). The negative traces from the past still burdens the reforms, making the process of transition as well as adopting the Environmental Acquis slow in general. However, after years of the stagnation of SAA agreement, Bosnia was given the boost to the process of accession to EU which could be used to start using pre-

\footnotetext{
${ }^{1}$ PhD Candidate, Faculty of Political Science, University of Sarajevo, Sarajevo, Bosnia and Herzegovina.
} 
accession funds and help the country to make the needed institutional reforms. In the paper we will in particular discuss potentials of the country to green its economy and whether the introduction of the principles of green economy at this stage could smooth the process of transition achieving positive results for the overall economy.

\section{TOWARD SUSTAINABLE DEVELOPMENT AND GREEN ECONOMY IN THE SEE TRANSITION COUNTRIES}

The transition process, although assisted by EU and many other international organizations, in most of the South Eastern European countries has not produced results in the expected time framework. Although the former Yugoslavian countries with so called 'mixed' economy system extent economic liberalization, political decentralization and permitted private ownership, poised with better prediction to make a successful transition to the market economy (Susan Woodward), this did not happen, except for Slovenia and to certain extent Croatia, which became the EU member in 2013.

The countries had common characteristics in their social and political background: they had for several decades socialistic and communist regimes on power as one party system and centrally planned economy. On the other hand, they featured substantial differences in terms of internal political organization, matters of public and private ownership, foreign policy affairs, etc. Also, with regard to geostrategic alliances, they did not choose the same path. While these different circumstances made each country to choose its own course in converting their systems into democratic and market economy societies, the process has been immensely burdensome for all: Serbia, FYR Macedonia, Bosnia and Herzegovina, Montenegro, Kosovo and Albania have all been undergoing a slow economic development, suffering from the high unemployment rate, low investment activities, unstable and inefficient institutions, weak private sector and infrastructure, insufficient investment in research work and an education system that will meet the market demands, etc.

In recent times, green economy has become an answer to environmental concerns and a driving policy of many developed countries in the world as it uses efficiently natural and ecosystem resources and services; it is socially inclusive, caring for marginalized such as women and poor, energy efficient significantly reducing risk to the environment, it creates new investments and consequently more jobs. Another definition talks about green economy as "the one that results in improved human well-being and social equity, while significantly reducing environmental risks and ecological scarcities" (UNEP 2010). Or even simpler: green economy can be thought of as one which is low carbon, resource efficient and socially inclusive. The concept features prominently in a range of medium and long-term strategies and programs, including the 7th Environment Action Program, the Europe 2020 Strategy, UNEP, EU Framework Program for Research and Innovation (Horizon 2020)' policies and programs in areas such as transport and energy, etc.

The high level of economic growth in many developed countries has been accomplished by utilization of technologies and traditional principles of development that heavily rely on natural resources thus causing misbalance in environment. In that sense it could be said that the more economy of a country is developed the greater is the urge for natural resources whose overuse causes environmental degradation. In many developed countries, the transition to high levels of economic and technical development has been achieved by adopting production and consumption patterns that heavily misbalances the environment. Conversely, countries which live within the limits of the planet have not (yet) managed to reach the level of the high development. 
For example, a country's energy consumption is strongly related to its level of economic development as in the case of SEE countries, mainly because SEE countries are less economically developed. These countries spend two to three times less energy per capita than EU countries, he higher a country's gross domestic product (GDP) the greater its energy needs. At the same time, to produce \$1 of GDP they require more energy relative to non-SEE EU countries. The Figure 1 shows that the countries of SEE are far less efficient than other countries in the continent. This inefficient use will require a strong focus on efficiency plans and programs and uptake of the most sustainable technologies and practices.

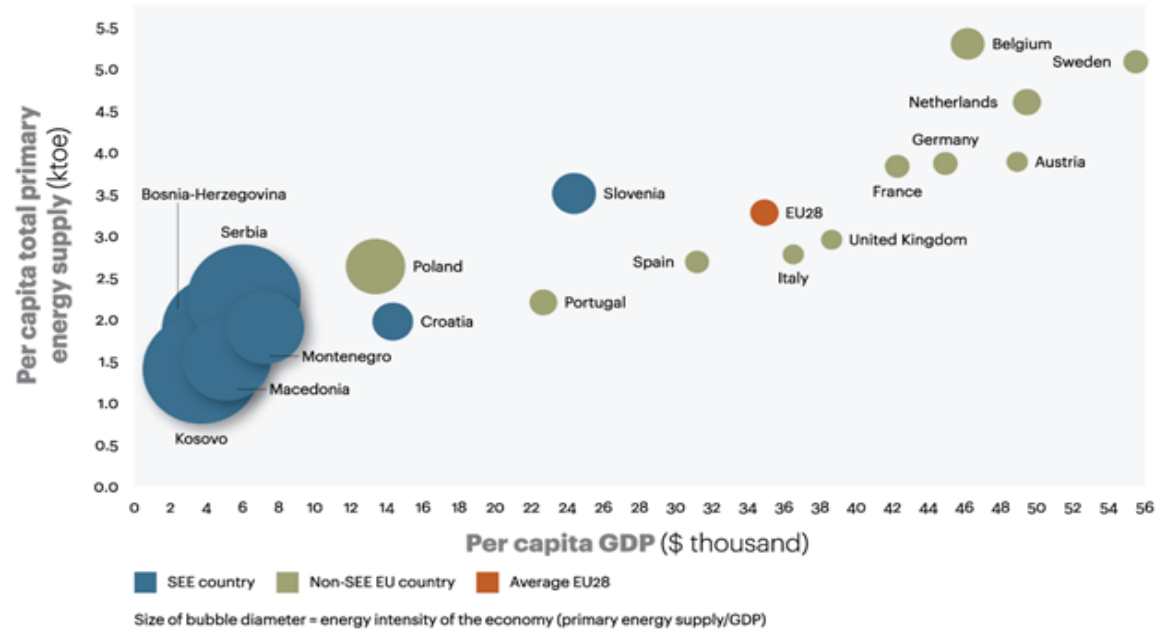

Notes: SEE is Southeast Europe; EU is European Union; ktoe is kiloton of oil equivalent on a net calorific bosis. Sources: International Energy Agency 2011 data for total primary energy supply, International Monetary Fund 2011 World Economic Outlook database for GDP, A.T. Kearney analysis

Fig. 1. Energy efficiency in SEE

The need of urgent development of the countries in transition poses a threat to the natural resources as the development in general is heavily leaned on their exploitation. It is obvious that there is an urging need for a new economic model that would be both sustainable and at the same time allows the economic and employment growth. In this context, the principles of green economy for the sustainable development comes as an only solution, taking into consideration the constant growth of human population, needs for the economic and technology development, and at the same time clean and healthy environment for the whole planet and future generations. The lack of sustainable development leads to inefficient economic development and to growing waste of resources and energy, on one hand, while, on the other hand, it entails huge costs with regard to pollution, harming human health and exhausting resources. It also creates a growing societal gap and increases the proportion of the poor and socially excluded.

Additionally, overused resources of highly developed countries direct them to rely to the resource of those less developed to meet their consumption demands. The urge for sustainable development of these countries in transition is therefore of mutual interest and requires a joint action as stated in the Agenda 21, the Rio Declaration on Environment and Development for: "the fulfillment of basic needs, improved living standards for all, better protected and managed ecosystems and a safer, more prosperous future. No nation can achieve this on its own; but together we can - in a global partnership for sustainable development". 


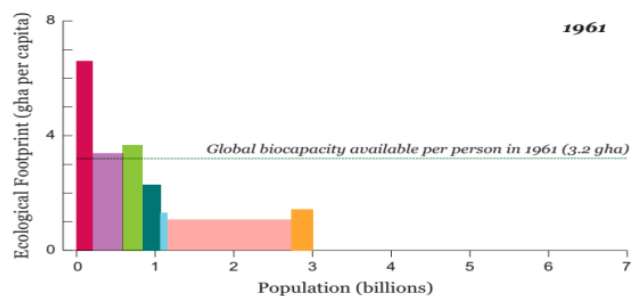

the average Ecologicat

Footprint per capita

and in population for

each geographic region

in 1961 and 2010

The area of each bar

represents the total

Footprint for each region

(Global

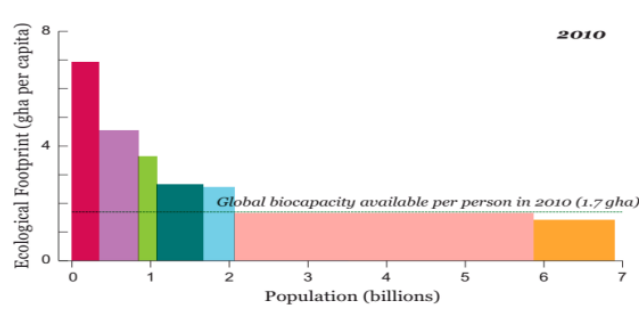

Key

Fig. 2 Ecological Footprint per Capita

The challenge SE European countries will face is to advance economic prosperity and human development significantly, to come close to the EU standard without expanding its footprint to the same levels as EU countries (see the Figure 2). Until now, the lower level of Ecological footprint of countries in transition was not yielded as a result of any midterm or short-term planning or strategic visions of the governments, but due to the different economic and politic circumstances. However, the prospects of growing economy in future pose a threat to resources and this urges for sustainable development strategies. Experiences of the countries with advanced or finalized stage of transition may be used as lessons or replication models to the countries in the process. Some, due to the complex institutional and ethnic structures such as Bosnia and Herzegovina, demand a specific tailor-made approach. Owing to its institutional complexity coupled with ethnic disagreements dating from the recent past, the process, even when it comes to the Environmental Acquis, calls for a particular strategy.

\subsection{Environmental Acquis in Bosnia and Herzegovina}

As stated in the Progress Report for Bosnia and Herzegovina (EC, 2014), the country is at a very early stage in aligning with the EU climate and Environmental Acquis and administrative capacity in these sectors remains weak. According to the $\mathrm{BiH}$ Constitution, the state level was not mentioned as the one authorized for environment, which automatically places environmental issues under the jurisdiction of the two entities, Federation of $\mathrm{BiH}$ and Republika Srpska. This makes environmental administration and regulatory control systems in many cases duplicate one another and very complex. In 2002-2004, a very important step forward was done toward harmonizing with the EU Environmental Acquis, under the leadership of EU (CARDS Program), when a set of environmental laws was adopted for each entity: that of environmental protection and environment protection fund, air, water protection and waste management. From that time, some bylaws and legal improvements to the legal frameworks for waste management, air, and water and energy have been done by entities. Although an Inter-Entity Environmental Body was established with certain coordination authorization, in reality not much has been done in environmental legislation at the state level: even though the adoption of the Law 
on Environmental Protection is one of the immediate priorities and requirements assumed in the processes of EU accession, the country has failed to adopt it. Besides, there is continuing lack of a national strategy for sustainable development. Instead, ethnic based interests continued to occupy the priority in the $\mathrm{BiH}$ policy agenda and this striving affected environmental sector in both entities.

However, this year (2015) for Bosnia and Herzegovina was marked with efforts to activate BiH's Stabilization and Association Agreement (SAA), after years of stagnation ${ }^{1}$. Upon the initiative which was made by Germany and the UK, a step forward was made to assist Bosnia and Herzegovina to overcome current social and economic problems, although the violation has not been cleared from the Constitution due to ethnic tensions. In a renewed and tailored-made approach, Bosnia and Herzegovina commits to implement various socio-economic, legislative and public institution reforms. One of the policy areas for cooperation referred to in Title VIII of SAA is the environment in which is stated: "The Parties shall develop and strengthen their cooperation in the environmental field with the vital task of halting further degradation and start improving the environmental situation with the aim of sustainable development. Cooperation could also centre on the development of strategies to significantly reduce local, regional and trans-boundary air and water pollution, including waste and chemicals, to establish a system for efficient, clean, sustainable and renewable production and consumption of energy, and to execute environmental impact assessment and strategic environmental assessment". (SAA, Article 108).

In the following chapter we will make a general overview of the country's potentials to green its economy and question whether the introduction of the principles of green economy at this stage could bring positive results to the overall economy.

\section{NEEDS AND PROSPECTS OF GREENING THE ECONOMY IN BOSNIA AND HERZEGOVINA}

In this paper we only made a general overview of some prospects and needs for green economy introduction in Bosnia and Herzegovina, including $\mathrm{CO} 2$ pollution decrease, resource efficiency, renewable energy. The following paragraphs for sure do not exhaust the potentials and chances for green economizing the country's resources. Also, the lack of coherent and consistent environmental data and analysis remains a serious impediment for a thorough analysis. For this purpose, we have compiled data from different reports and studies, and the following are the findings of the World Bank, IEA, UNECE, ENERDATA, SNC (Second National Communication) applying different methodologies.

\subsection{Carbon dioxide}

One of the main principles of green economy is decrease of carbon dioxide emission. In Bosnia and Herzegovina, the level of carbon dioxide before the last war amounted to 24.9 mil. t. Although the recent figures are not even close to these, they show continuous increase: emissions in 2005 were 3.6 per cent higher than in the previous year and 15.0 per cent higher than in 2000. In 2007, the International Energy Agency (IEA) estimated total

\footnotetext{
${ }^{1}$ SAA has been signed in 2008, ratified in 2010, and entered into force in 2015. The agreement had to be frozen before it could enter into force because in 2009 Bosnia was found in violation of the European Convention on Human Rights in the famous Sejdic and Finci ECtHR case.
} 
$\mathrm{CO} 2$ emissions at $16.3 \mathrm{Mt}$, broken down as follows: energy sector (52 percent), construction and agriculture (16 percent), transport 14 percent), industry (13 percent), and residential ( 5 percent). Emissions have tripled since 1995, and increased by $21 \%$ between 2000 and 2004 as energy consumption increase due to an increased energy demand that emerged with renewed economic growth. At the same time, the percentage on coal dependency is same to the one from 1990, which amounts between 60 to 65 percent of TPES (Total Primary Energy Supply) with the total share of all fossil fuels reaching over $94 \%$ in 2009 . The country's reliance on domestic coal has remained almost unchanged since 1990 (between 60 to 65 percent of TPES). Coal accounts for 75 percent of emissions, followed by oil products (21 percent) and natural gas (4percent). As a result BiH's carbon intensity is one of the highest in the Western Balkans.

Although the greenhouse gas emissions in Bosnia and Herzegovina are estimated to grow by almost 30 per cent between 2005 and 2030 (UNECE 2011) until now there is no strategic switch or plan to lower-carbon fuels.

A challenge in coming years is presented in the outdated coal-fired power plants in order to reduce adverse environmental impact. Improvements can be made in transmission/distribution process (21\% loss in 2008), and increase of efficiency of thermo plant, as $22 \%$ is significantly low (Enerdata).

\subsection{Renewable Energy}

Having in mind that the main source of $\mathrm{CO} 2$ is the energy production sector, the increase of renewable energy sources would significantly affect the total $\mathrm{CO} 2$ emissions. $\mathrm{BiH}$ has great potentials in renewable energy, at the moment using mainly hydropower potential.

There is a signifiant potential of solar energy application on the $\mathrm{BiH}$ territory. The technical potential totals $685 \mathrm{PJ}$, which is 6.2 times higher than the total primary energy needs in the energy balance of $\mathrm{BiH}$.

Wind power has one of the most significant energy potentials in Bosnia and Herzegovina. Several studies that have been done for Podvelezje area, showed that economic potential of wind energy could reach $600 \mathrm{MW}$ of electrical power by 2020.

Based on the research results from $\mathrm{INC}$, it is estimated that the economic hydropower potential of major waterways in $\mathrm{BiH}$ is around 18,000 $\mathrm{GWh} /$ year and for small streams is $3,500 \mathrm{GWh} /$ year. Only $40 \%$ of the total economic potential is currently realized.

Bosnia and Herzegovina continues to operate without a national renewable energy action plan, as required by the Energy Community Treaty. Significant hindrance to full renewable energy sector development lies in limited incentives for renewable energy projects in both entities, openness to private sector investment and market regulation.

\subsection{Resource/Energy Efficiency}

In terms of resource efficiency, which is one of the crucial aspects of green economy principles, in Bosnia and Herzegovina both public and private sector organizations and companies inefficiently use their resources and energy, as a consequence having high cost for energy and at the same time causing environmental degradation. Lack of a systematic approach to energy efficiency enhancement is evident as well as insufficient utilization energy management.

High levels of losses in the process of energy transformation are estimated at about 50 percent of TPES. Inefficient conversion of primary energy (particularly in power 
generation) is due largely to outdated equipment and technologies due to lack of maintenance and spare parts, and the slow replacement of obsolete units, and to the limited share of combined heat and power (CHP) in the energy mix. Energy end-use is inefficient: public buildings are generally poorly insulated and the estimated potential for energy savings ranges between 30 percent and 35 percent, thus indicating a huge potential for reducing the burden of energy expenses in both public and private sectors. In addition, since the gas distribution network is not fully connected, the majority of the heating requirement of the households is fulfilled by the inefficient use of electricity.

Improving EE would also yield positive economic value through increased employment, more competitive economies, and eventually increased power exports. However, primarily, a financing support mechanism for EE investments should be established. Obstacle to improving energy efficiency in $\mathrm{BiH}$ is the lack of a clear regulatory and policy framework, although the both entity governments have recognized the importance of the issue, and efforts have been made to develop an appropriate legal framework.

\section{CONCLUSION}

Green economy is low-carbon, resource efficient, and socially inclusive. In a green economy, growth in income and employment are driven by public and private investments that reduce carbon emissions and pollution, enhance energy and resource efficiency, and prevent the loss of biodiversity and ecosystem services. At the same time, by introducing green projects it increases chances for employment. This concept, taking into consideration natural resources of the most SEE countries and their expected growth, features as the best possible reconciliation pattern for economic growth and environmental and resource protection. Bosnia and Herzegovina, in the light of economic, social and political transition process is in a specific position among the countries in the region. The country suffers obstacles to the development and integration mainly due to an inefficient political system which is the result of the Dayton Peace Agreement. This extremely complex institutional architecture of the country remains inefficient and is misused (Commission Staff Working Document, 2010), and presents the main impediment for $\mathrm{BiH}$ not only for Environmental Acquis, but for its progress in general.

At the same time the urge for development is growing and new prospects have been opened with the new approach of EU and the country's commitment. In the paper we overviewed main points for turn to green economy. It is clear that the green economy can become an answer to both environmental and economic growth concerns and driving policy of the country as it uses efficiently natural and ecosystem resources and services and it is socially inclusive. The following are just main and urgent points to be applied in order to green the country: a)Establishment of State Agency for Environment and adoption of the Law on Environment on state level; b)Support to reconstruction or replacement of existing thermo plant capacities; c) Establishing an EE framework for increase of energy efficiency in public and private sector; d) Adopt a National Renewable Energy Plan; e) Official policy of renewable energy promotion and energy efficiency; f) Wide promotion of sustainable development importance; g) Stregthening legal and institutional framework (incentives) for renewable energy use; h) Greening' the public procurement

The system of the green economy cannot be copied from the developed countries, due to factors that origin from different historical backgrounds. It should be systematically and strategically introduced and EU should facilitate the system of introduction. One of the ways to induce the green economy is through 'greening' the public procurement. In 
addition, taxing environmentally damaging activities can raise revenues and establish environmental discipline.

For Bosnia and Herzegovina, the new boost toward the candidateship might open a new path toward the economy recovery as it offers concrete support to the reforms, primarily through the access of the funds. This moment could be used to start intensively "green" the market, products and establish a systematic and strategic protection of the environment that will open the way to finalize the Environmental Acquis.

\section{REFERENCES:}

1. Carter Francis and Turnock David (2002): Environmental Problems in Eastern Europe, London: Routledge

2. Susan L. Woodward (1995): Balkan Tragedy: Chaos and Dissolution after the Cold War, Washington: Brookings Institution

3. European Commission (2014): Bosnia and Herzegovina Progress Report, Retrieved from: http://ec.europa.eu/enlargement/pdf/key_documents/2014/20141008-bosnia-andherzegovina-progress-report en.pdf

4. EEA, (2015), The European environment - state and outlook 2015: synthesis report, European Environment Agency, Copenhagen

5. International Energy agency (2012) Energy in the Western Balkans http:/www.iea.org/publications/freepublications/publication/balkans2008.pdf

6. NEAA (2014): Trends in Global CO2 Emission, Report, Hague, 2014, retrieved from: $\quad$ http://edgar.jrc.ec.europa.eu/news docs/jrc-2014-trends-in-global-co2emissions-2014-report-93171.pdf

7. Second National Communication of Bosnia and Herzegovina under the UN Framework Convention on Climate Change (2013), retrieved from: http://unfccc.int/resource/docs/natc/bihnc2.pdf

8. WWF International(2014): Living Planet Report, Available at: http://d2ouvy59p0dg6k.cloudfront.net/downloads/wwf_lpr2014_low_res_full_rep ort.pdf

9. Cenic, Svetlana (2012): Resource Efficiency Gains and Green Growth Perspectives in Bosnia and Herzegovina, Study, Friedrich Ebert Stiftung

10. United Nation Economic Commission for Europe (2011): $2^{\text {nd }}$ Environmental Performance Review: Bosnia and Herzegovina, Geneva: UN Publications

11. UNECE, (2011), $2^{\text {nd }}$ Environmental Review, Geneva and New York

12. UNEP, (2011), Towards a green economy: pathways to Sustainable Development and Poverty Eradication, retrieved from: http://www.unep.org/greeneconomy/Portals/88/documents/ger/ger final dec 2011 /Green\%20EconomyReport Final Dec2011.pdf

13. JRC/PBL: Emissions Database for Global Atmospheric Research (EDGAR) https://ec.europa.eu/jrc/en/scientific-tool/emissions-database-global-atmosphericresearch ( 20 August, 2015)

14. United Nations Conference on Environment \& Development (1992): AGENDA 21 Rio de Janerio, Brazil, retrieved from: https://sustainabledevelopment.un.org/content/documents/Agenda21.pdf (22 June, 2015) 